\title{
Cross-curricular collaboration in teaching social aspects of genetics
}

Paper presented at the Fourth International Conference of the European

Science Education Research Association, August 19-23, Noordwijkerhout, The Netherlands

\author{
Mary Ratcliffe, Richard Harris, Jenny McWhirter, Mary Thomas. \\ University of Southampton, UK \\ Email: m.ratcliffe@soton.ac.uk
}

\begin{abstract}
Science teachers can lack pedagogic skill and confidence in handling multifaceted socio-scientific issues. This project has explored the development, implementation and evaluation of a 'cross-curricular' day as a suitable vehicle in 8 different schools for both engaging 14-16 year old pupils in active consideration of social aspects of genetics and enabling science and humanities teachers to collaborate in planning and delivery. The crosscurricular research team planned a programme of activities, involving volunteer teams of teachers in development. Pupils in participating schools generally found the day stimulating, increasing their understanding of genetics and appreciation of social aspects. However, implementation showed that some teachers missed important learning opportunities. The paper explores the nature and implications of cross-curricular collaboration for increasing pupils' engagement with social and ethical aspects of biomedical science and science teachers' pedagogic skill.
\end{abstract}

\section{Introduction}

The project reported here was commissioned and funded by the Wellcome Trust - an independent biomedical research charity which aims to improve human and animal health. A previous project commissioned by the Wellcome Trust - Valuable Lessons: engaging with the social context in schools (Levinson and Turner, 2001) - explored the extent to which the teaching of social and ethical aspects of science was already part of teachers' repertoire. Levinson and Turner (2001) found that science teachers addressed social aspects of biomedical science infrequently and with lack of confidence. Although humanities teachers showed greater willingness to engage pupils in such discussion, few teachers of any discipline addressed ethical aspects of scientific advancements.

Levinson and Turner's study recommended that a 'collapsed' or crosscurricular day in which science and humanities teachers collaborate in design and delivery might be an effective way of engaging pupils with socio-scientific issues. They suggested that formal collaboration may be effective if the following features are in place:

- 'learning group off formal curriculum timetable;

- planning between teachers of different subject areas, particularly English, RE and science;

- an integrated model of teaching;

- assessment through one particular subject area; and 
- equal participation by all teaching partners in terms of decisionmaking.' (Levinson \& Turner, 2001: 62)

These suggestions arose from a synthesis of teachers' views but with little empirical basis. The aim of our project was thus to explore the feasibility and effectiveness of cross-curricular collaboration through the development, implementation and evaluation of a programme for a 'collapsed day' on a biomedical issue, examining the barriers, opportunities and outcomes at each stage.

The difficulties of addressing social and ethical implications of advances in scientific research in schools are related to at least three factors:

- the nature of the socio-scientific issues themselves;

- the pedagogical strategies adopted by teachers of different disciplines;

- the compartmentalised nature of the secondary curriculum.

\section{Nature of socio-scientific issues}

Socio-scientific issues are multi-faceted. In summary, (Ratcliffe \& Grace, 2003) socio-scientific issues:

- have a basis in science, frequently at the frontiers of scientific knowledge;

- involve forming opinions, making choices at a personal or societal level; - are frequently media-reported, with attendant issues of presentation affected by the purposes of the communicator;

- deal with incomplete information because of conflicting and/or incomplete scientific evidence, inevitably incomplete reporting;

- may have local, national and global dimensions;

- involve some cost-benefit analysis in which risk interacts with values;

- may involve consideration of environmental sustainability;

- involve values and ethical reasoning;

- may require some understanding of probability and risk;

- are frequently topical with a transient life.

The multi-faceted nature of socio-scientific issues suggests that for individuals to develop an informed view on any issue they should have a good understanding of all the aspects - i.e. underpinning science concepts and the nature of science; nature of decision-making processes, probability and costbenefit analysis; nature of media-reporting; social context of the issue; personal and societal value judgements and ethical reasoning. These facets can be explored atomistically within different subject areas, but this approach runs the risk that full holistic consideration of the issue does not occur. This project deliberately took a holistic approach. Aspects of genetics were chosen as a focus in this project because these emerged as most popular with teachers in an initial survey. Advances in gene therapy and genetic engineering raise issues of both private and public morality (Warnock, 2001). Understanding of the nature of scientific endeavour, risk, decision-making and media reporting are important in considering the social aspects of genetics for example, the implications for individuals and society of genetic testing. A 'collapsed day' implies a holistic approach in which the different facets of the issue are brought together. Thus, one aspect explored in this project was the extent to which the different facets were addressed and supported in design and delivery of a 'collapsed day' programme. 


\section{Pedagogical strategies}

Socio-scientific issues raise pedagogical challenges for teachers. Key considerations are the nature of intended learning outcomes for pupils when considering the issue at a holistic level and how these are best supported.

There may be a hierarchy of purposes, when considering an issue holistically, from sharing individual perspectives on the issue; reaching an understanding of the variety of available subjective responses; making a choice between differing values; to finding a rational resolution of the controversy (Bridges, 1979). Humanities and science teachers canvassed by Levinson and Turner gave a variety of justifications for teaching social and ethical aspects of biomedical science, with 'sensitivity' and decision-making being the most frequent. These reasons seem similar to the two extremes of Bridges' (1979) hierarchy of purposes. Little attention was given to ethical analysis by any teachers (Levinson and Turner, 2001). Members of the research team have encountered many instances where the potential for discussion and analysis of socio-scientific issues has not been fully exploited in science classrooms, resulting in some cases in amorphous discussion or rapid decision-making (Ratcliffe \& Grace, 2003). Despite limited attention in many classrooms to socio-scientific issues, research evidence of innovative practice has provided some understanding of pupils' use of values, beliefs and scientific knowledge when dealing with socio-scientific issues in science lessons and how these relate to the pedagogical issues facing science teachers (Solomon, 1992; Gayford, 1993; Ratcliffe 1997,1999). Such case study research supports the value pupils place on the opportunity to discuss socio-scientific issues and highlights the need for:

0 an emphasis on the process of analysis of an issue and reflection on the process (rather than the outcome);

0 clarity in specifying and sharing intended learning outcomes, given the multiplicity of possible learning outcomes;

o clear structure in the activity;

o clarity in the supportive role adopted by the teacher.

The research team considered these as important pointers for constructing activities and teaching strategies for 'collapsed days'. It was anticipated that peer group discussion and/or focused group tasks would form important activities during the day, allowing support by both science and humanities teachers. Humanities teachers may be more comfortable than science teachers with supporting critical small group discussion; science teachers may be comfortable than humanities teachers with the scientific underpinnings of the activity. Such considerations informed the development of the framework for the day (see Methods page 7).

\section{Cross-curricular collaboration}

A 'collapsed day' gives a clear opportunity for collaboration between science and humanities teachers in design and delivery. Throughout this project, 'humanities' is treated broadly as comprising English and drama, history, geography, RE, PSHE (Personal, Social and Health Education) and citizenship (where there was a designated co-ordinator for this newly introduced National Curriculum subject). 
Just as the implementation in schools was expected to be cross-curricular, it was important that the research team was also cross-disciplinary. Thus the team had expertise in science education (Mary Ratcliffe), PSHE (Jenny McWhirter, Mary Thomas), history education (Richard Harris), and genetics research (Carly Brooks). In addition the team worked closely with the project instigator at the Wellcome Trust (Helen Lewis).

Cross-curricular collaboration in dealing with socio-scientific issues seems currently rare. In one example, Huckle (2001, p158) describes how geography and English departments in secondary schools co-operated in engaging with the genetically modified food debate through pupils' use and evaluation of information on relevant websites. It is concerning, but understandable, that science departments were not engaged in this cross-curricular initiative. Examination of media reports and social issues are more prominent in humanities curricula which can result in discussion of socio-scientific issues without clear consideration of the underpinning science. There is limited research evidence to address factors in cross-curricular collaboration on socio-scientific issues. For example, $\operatorname{Kerr}(1999, \mathrm{p} 9)$ highlights the many gaps in our knowledge and understanding of citizenship education: such as pupils' development of social knowledge; relationship between pupils' knowledge, attitude and beliefs; outcomes of citizenship education programmes.

Principles of a holistic cross-curricular approach, in which the multi-faceted socio-scientific issue was supported by appropriate pedagogical strategies, underpinned the design and implementation of the 'collapsed day' programme. Given the limited research base, our research questions focused particularly on the cross-curricular collaboration - its processes and outcomes:

o What are the learning outcomes for pupils from a 'collapsed day' on social aspects of genetics?

0 What are the gains and barriers for teaching and learning in crosscurricular collaboration?

o What are the opportunities and barriers for teachers in their planning for and delivery of 'collapsed days' in principle and in practice? In answering these questions we sought to establish the feasibility of collapsed days as a method of effective engagement of pupils with a socioscientific issue and the extent and value of cross-curricular collaboration as an approach to the teaching of a socio-scientific issue.

\section{Methods}

The project had three phases - exploration of the feasibility in principle of 'collapsed days' for biomedical science; development of a collapsed day programme, in conjunction with participating teachers; evaluation of implementation of the programme in eight schools. This paper concentrates on the third phase - evaluation of implementation of the programme, with some background on the first two phases.

\section{Phase 1 Feasibility in principle}

Feasibility of 'collapsed days' in principle was explored by postal questionnaire to all secondary schools (383) in the South of England, with separate questionnaires to headteachers, heads of science and heads of 
humantities. This questionnaire both sought views on the feasibility of a collapsed day for a biomedical science issue and also sought to recruit schools to participate further in delivery. Thus responses (from 127 different schools) tended to be from teachers positively disposed to the project.

The feasibility questionnaire gave information about potential opportunities and barriers in taking a year group off timetable, including: curricular links; types of expected learning outcomes and activities; nature of cross-curricular collaboration and its management; possible biomedical topics; timing and logistics of organising the day. Preliminary analysis of questionnaires proceeded in parallel with the design of an outline framework for the collapsed day programme by the research team. Thus, the feasibility questionnaire was able to inform the biomedical topic for the programme, with social issues of genetics, e.g. genetic engineering and gene therapy, emerging as the most popular.

Phase 2 Development of collapsed day programme and sharing with teachers The research team designed an outline programme which was then shared with teachers and developed further. Some key principles underpinned the design of the programme at two levels: the nature of the cross-curricular delivery overall; the nature of proposed activities and their expected learning outcomes.

\section{Overall delivery}

Two complementary aims of the project were important in shaping the criteria for the design and delivery of the programme:

o The development of an approach that was sustainable and manageable within schools.

0 The intention to engage both science and humanities teachers in delivery or support of the programme - sharing expertise.

The research team felt that ownership of the programme by teachers was a key element in fulfilling these aims. Design and delivery by a team external to the school would allow evaluation of pupil learning but give little information about the feasibility or sustainability of cross-curricular collaboration as a means of addressing socio-scientific issues. Thus, the research team designed a collapsed day framework, which could be adapted to local circumstances but which, if all elements were addressed, would have some consistency in delivery across different schools.

\section{Cross-curricular collaboration}

The nature of cross-curricular collaboration in design and delivery can take a number of forms (Figure 1). The research team advocated approach $C$ as an opportunity for full cross-curricular collaboration. However, there may be limitations to the feasibility of such an approach. The nature of cross-curricular collaboration in practice was one element explored in evaluation of implementation.

Figure 1 Hierarchy of approaches in cross-curricular design and delivery

A. Planning as a team, with each curriculum area indicating their expertise or the nature of the specialist activity they could support. 
Each area contributes a specialist activity taught by those specialists.

There is limited sharing of approaches and activities by teachers.

The programme is not delivered by cross-curricular teams.

B. Planning as a team, with each curriculum area indicating their expertise or the nature of the specialist activity they could support.

Each area contributes a specialist activity which is taught by either a specialist or non-specialist according to the desire to maintain either a common order of activities for all pupils or continuity of contact between teacher and group of pupils during the day.

There is sharing of approaches, activities and expertise by teachers.

The programme is not delivered by cross-curricular teams.

C. Planning as a team, with each curriculum area indicating their expertise or the nature of the specialist activity they could support.

Each area contributes a specialist activity or specialisms are combined in a joint activity.

Each activity is supported by teachers from contrasting disciplines.

There is sharing of approaches, activities and expertise by teachers.

The programme is delivered by cross-curricular teams.

Nature of learning activities - detail of programme design

The research team took a cross-curricular approach in designing an outline programme for the collapsed day, spending time in sharing perspectives and suitable teaching strategies from our respective curriculum areas. This sharing reflects the processes which might be necessary in schools in reaching mutual understanding of the nature of teaching in complementary disciplines. The team agreed, from the research base and teaching experience, a number of criteria which the programme had to fulfil in terms of expected learning, cross-curricular teaching and management:

\section{A Pupils' Learning}

In addressing the complexity of socio-scientific issues:

i) The activities should have clear intended learning outcomes which support pupil discussion AND ethical reasoning - i.e. activities have the potential to go beyond sharing of views helping pupils to identify and engage with the complexity of the issue and to recognise and be able to apply the process of ethical reasoning in other contexts.

ii) The science content should be accessible to a wide ability range, have clearly identifiable links to aspects of the science curriculum and represent advancing knowledge in an aspect of biomedical science.

iii) Resources and activities should be seen as stimulating and topical by pupils and teachers.

iv) Assessment of intended learning outcomes through written or oral outcomes generated by pupils contribute towards achievement in science and/or citizenship.

v) Follow-up work is identified which has clear ownership by pupils and teachers in the target school

\section{B Cross-curricular collaboration and teaching strategies}

i) The programme involves teachers of different disciplines in contributing relevant expertise to support pupil learning 
ii) Teaching strategies support pupil discussion AND ethical reasoning - i.e. teaching strategies allow pupils to engage with the complexity of the issue and to recognise and be able to apply the process of ethical reasoning in other contexts.

iii) The whole programme of activities should be seen as pertinent and interesting to both science and humanities teachers.

\section{Management and organisation}

i) The programme should be sufficiently flexible to allow it to be delivered to year groups of different sizes and within the accommodation available within individual schools.

ii) Delivery of the programme should be sustainable - i.e. teachers should feel confident they could develop and manage further collapsed days on similar topics.

From the initial criteria and discussion of teaching strategies and resources, the framework shown in Figure 2 was developed. The framework was designed to match the criteria discussed above and produce a collapsed day programme in which key questions were addressed and outcomes synthesised through pupils engaged in team work - What do we know? What are people's views? How should we decide?

The framework shows how teaching strategies were designed to match intended learning outcomes. In advance of working with teachers during a development day, the research team devised or adapted resources to produce activities which could be exemplified to teachers and form a basis for discussion. 
Figure 2 Framework for a collapsed day programme to consider the social and ethical implications of advancements in genetics

\begin{tabular}{|c|c|c|c|}
\hline & $\begin{array}{l}\text { Intended Learning } \\
\text { Outcomes }\end{array}$ & Activities: & Teacher's role \\
\hline $\begin{array}{l}\text { Introduction } \\
\text { (pupil team } \\
\text { building) }\end{array}$ & $\begin{array}{l}\text { To recognise the roles } \\
\text { and responsibilities of } \\
\text { working in a team } \\
\text { To establish initial views } \\
\text { and understanding of } \\
\text { genetics / genetic } \\
\text { engineering }\end{array}$ & $\begin{array}{l}\text { Team building activity } \\
\text { Establishing initial } \\
\text { views and } \\
\text { understanding }\end{array}$ & $\begin{array}{l}\text { Managing the team } \\
\text { building activity; } \\
\text { Clarifying initial views } \\
\text { and understanding of } \\
\text { pupils - how the day will } \\
\text { address their views and } \\
\text { understanding. }\end{array}$ \\
\hline $\begin{array}{l}\text { Stimulus } \\
\text { (for considering } \\
\text { social aspects } \\
\text { of genetics) }\end{array}$ & $\begin{array}{l}\text { To explore reactions to a } \\
\text { human dilemma } \\
\text { involving genetic } \\
\text { disorders } \\
\text { To start to identify the } \\
\text { scientific aspects, the } \\
\text { individual views and the } \\
\text { wider societal impact. }\end{array}$ & $\begin{array}{l}\text { Watching and } \\
\text { discussing video or } \\
\text { other source material } \\
\text { (resource - What's the } \\
\text { message?) }\end{array}$ & $\begin{array}{l}\text { Organising the } \\
\text { video/other stimulus; } \\
\text { managing peer group } \\
\text { discussion } \\
\text { [In practice, external } \\
\text { speakers were used in } \\
\text { most schools] }\end{array}$ \\
\hline $\begin{array}{l}\text { Science - } \\
\text { What is } \\
\text { possible? }\end{array}$ & $\begin{array}{l}\text { To be able to show } \\
\text { appropriate } \\
\text { understanding of genes, } \\
\text { genetic crosses, genetic } \\
\text { engineering }\end{array}$ & $\begin{array}{l}\text { Activities related to } \\
\text { developing under- } \\
\text { standing of genetics / } \\
\text { genetic engineering }\end{array}$ & $\begin{array}{l}\text { Explaining scientific } \\
\text { concepts, managing } \\
\text { literacy activity / } \\
\text { practical work }\end{array}$ \\
\hline $\begin{array}{l}\text { Science } \\
\text { extension - } \\
\text { How do we } \\
\text { know? }\end{array}$ & $\begin{array}{l}\text { To be able to explain the } \\
\text { methods by which } \\
\text { scientific evidence can } \\
\text { be collected and } \\
\text { evaluated by peer } \\
\text { review; } \\
\text { To be able to evaluate } \\
\text { the presentation of } \\
\text { scientific evidence in } \\
\text { media reports }\end{array}$ & $\begin{array}{l}\text { Use appropriate media } \\
\text { reports -newspaper } \\
\text { articles, New Scientist } \\
\text { articles. } \\
\text { Evaluation questions } \\
\text { answered as a group }\end{array}$ & $\begin{array}{l}\text { Explaining the nature of } \\
\text { scientific evidence, its } \\
\text { collection and its } \\
\text { limitations. Managing } \\
\text { peer group discussions } \\
\text { to explore the nature of } \\
\text { media presentations. }\end{array}$ \\
\hline $\begin{array}{l}\text { Genetic } \\
\text { testing - } \\
\text { where do we } \\
\text { start and } \\
\text { stop? }\end{array}$ & $\begin{array}{l}\text { To identify views as an } \\
\text { individual to the issue of } \\
\text { genetic testing } \\
\text { To recognise the } \\
\text { difficulties in where we } \\
\text { draw the line - the } \\
\text { slippery slope } \\
\text { arguments. }\end{array}$ & $\begin{array}{l}\text { 'Heads and Hearts'; } \\
\text { Debrief and } \\
\text { discussion - where do } \\
\text { we draw the line? How } \\
\text { does society decide? } \\
\text { Who should have } \\
\text { access to genetic } \\
\text { information? }\end{array}$ & $\begin{array}{l}\text { To introduce genetic } \\
\text { testing; to manage } \\
\text { whole group activity and } \\
\text { subsequent discussion }\end{array}$ \\
\hline $\begin{array}{l}\text { How should } \\
\text { we decide? }\end{array}$ & $\begin{array}{l}\text { To recognise some } \\
\text { principles of ethical } \\
\text { decision-making: goals, } \\
\text { rights, responsibilities; } \\
\text { To be able to engage in } \\
\text { ethical analysis }\end{array}$ & $\begin{array}{l}\text { Ethical analysis using } \\
\text { Goals, Rights, } \\
\text { Responsibility } \\
\text { framework }\end{array}$ & $\begin{array}{l}\text { To introduce a particular } \\
\text { problem - e.g. living } \\
\text { with cystic fibrosis; to } \\
\text { manage peer group } \\
\text { ethical analysis }\end{array}$ \\
\hline $\begin{array}{l}\text { Can we? } \\
\text { Should we? -- } \\
\text { Our views }\end{array}$ & $\begin{array}{l}\text { To synthesise and } \\
\text { present arguments } \\
\text { related to: What is } \\
\text { possible? How should } \\
\text { we decide? (How do we } \\
\text { know?) }\end{array}$ & $\begin{array}{l}\text { Team-based synthesis } \\
\text { of views and evidence } \\
\text { e.g. radio/TV report/ } \\
\text { poster /drama / written } \\
\text { report / letter }\end{array}$ & $\begin{array}{l}\text { To manage the peer } \\
\text { groups as they devise } \\
\text { and present outcomes } \\
\text { from consideration of } \\
\text { the rest of the day's } \\
\text { activities }\end{array}$ \\
\hline
\end{tabular}


The results of the initial feasibility questionnaire allowed identification of a number of schools that were willing to undertake delivery of a collapsed day during the Autumn term 2002. Two types of participating school were identified:

i) Seven schools were recruited to work with the research team during a development day in July 2002 in which the framework, activities and teaching strategies were exemplified and discussed. In order to build in cross-curricular planning in schools from the outset, three teachers from each participating school were invited to attend this development day - including at least one science teacher and at least one 'humanities' teacher. It was expected that these teachers would take the lead role in organisation and development within the school with the support, as needed, of the research team.

ii) Four 'host' schools were recruited to deliver the programme in their school without attending the development day.

Three of the seven schools participating in the development day initially volunteered to lead or support delivery of the programme in each of these four schools. The intention of implementation in this way was to explore a form of external delivery and issues of transfer of the programme, by those who had engaged in its design, to delivery by those who had not experienced the activities first hand.

Three teachers from each of the seven 'lead' schools attended a development day in July 2002. The aims of the development day with teachers were:

- To present the draft programme in an interactive fashion, for final negotiation for similarity across all schools;

- To engage teachers in the programme through modelling the activities to be undertaken by pupils;

- To establish teachers' views of the design and proposed delivery of the programme.

Field notes were taken during the day to record the nature of presentation and teachers' actions. Focus group discussions held at the end of the development day also established teachers' reactions to design and delivery. These discussions were transcribed and used as a record of participating teachers' initial perceptions.

From the transcribed discussion, the major challenges identified by teachers attending the development day were:

o further development of activities which would be stimulating for pupils;

0 the nature of cross-curricular planning in order to address advancements in genetics, social implications and decision-making;

0 the extensive time needed for the level of planning in the school to allow effective cross-curricular planning;

0 the logistical issues which the implementation raised within each school. 
Phase 3 Evaluation of implementation

A number of research instruments were used to collect data about the implemented programme and its impact on pupils and teachers. Pupils' reactions to the collapsed day were canvassed in three ways. Two classes in each school were followed during the event and field notes of the activities undertaken were made by two researchers, focussing on pupils' apparent engagement in the activities and the nature of teachers' actions. Pupils in these two classes completed a questionnaire immediately after the event seeking their views on learning, interest and participation. Within a couple of days, focus group discussions were held with two small groups of pupils, in most cases drawn from the two classes observed. The delay of 24 hours or more in most cases allowed pupils to reflect on their experience. The focus group discussions were able to explore in some depth pupils' views on their learning, interest and participation and added further detail to the evidence from observation and pupil questionnaires.

Questionnaires were also administered to all participating teachers for return with a couple of days of completion of the event. In addition at the end of the event, in all schools there was discussion with teachers in which they shared their immediate reactions to delivery of the programme.

Questionnaires to teachers and pupils were similar in construction to the feasibility questionnaire, focussing on pupils' learning and motivation; crosscurricular collaboration; management and logistics. Similarly, field notes and pupils' focus group discussions concentrated on pupils' engagement; the nature of activities as implemented and teachers' roles. Table 1 shows the nature and extent of the data collected across all schools.

Table 1 Data collection related to planning and implementation

\begin{tabular}{|c|c|c|c|c|c|}
\hline & School type & $\begin{array}{l}\text { No. of } \\
\text { classes }\end{array}$ & $\begin{array}{l}\text { Attended } \\
\text { Development } \\
\text { day }\end{array}$ & $\begin{array}{l}\text { Teacher } \\
\text { data } \\
\text { collected }\end{array}$ & $\begin{array}{l}\text { Pupil data } \\
\text { collected }\end{array}$ \\
\hline 1 & $\begin{array}{l}\text { suburban 11- } \\
16 \text { mixed } \\
\text { comprehensive }\end{array}$ & $\begin{array}{l}7 \\
(2 \mathrm{obs})\end{array}$ & $\begin{array}{l}2 \\
\mathrm{RE} E^{*} \mathrm{Sci}\end{array}$ & $13 / 14$ qs & $\begin{array}{l}40 \mathrm{qs} \\
(90 \%) \\
1 \mathrm{FG}(8 \\
\mathrm{ps})\end{array}$ \\
\hline 2 & $\begin{array}{l}\text { rural 11-16 } \\
\text { mixed } \\
\text { comprehensive }\end{array}$ & $\begin{array}{l}4 \\
\text { (2 obs) }\end{array}$ & $\begin{array}{l}3 \mathrm{RE}^{*} \mathrm{Sci} \\
\text { Hist }\end{array}$ & n & $\begin{array}{l}25 \text { qs } \\
(90 \%) \\
2 \mathrm{FG}(2 \times 5)\end{array}$ \\
\hline 3 & $\begin{array}{l}\text { suburban 11- } \\
18 \text { mixed } \\
\text { comprehensive }\end{array}$ & $\begin{array}{l}9 \\
\text { (2 obs) }\end{array}$ & $\begin{array}{ll}3 & \mathrm{RE} \\
\mathrm{Sci}^{*} \text { Eng }\end{array}$ & $\begin{array}{l}7 / 9 \text { qs } \\
3 \text { discn }\end{array}$ & $\begin{array}{l}32 \mathrm{qs} \\
(80 \%) \\
2 \mathrm{FG}(2 \times 5)\end{array}$ \\
\hline 4 & $\begin{array}{l}\text { urban 11-16 } \\
\text { girls' } \\
\text { comprehensive }\end{array}$ & obs) & $\begin{array}{l}3 \text { Hum Sci* } \\
\text { Geog }\end{array}$ & & $\begin{array}{l}14 \mathrm{qs} \\
(50 \%) \\
1 \mathrm{FG}(6)\end{array}$ \\
\hline 5 & $\begin{array}{l}\text { urban 11-16 } \\
\text { girls' } \\
\text { comprehensive }\end{array}$ & $\begin{array}{l}8 \\
\text { (2 obs) }\end{array}$ & $\begin{array}{lc}3 & \mathrm{RE} \\
\mathrm{Sci}^{*} & \mathrm{Sci}\end{array}$ & $\begin{array}{l}\text { qs } \\
\text { sen }\end{array}$ & $\begin{array}{l}37 \text { qs } \\
(90 \%) \\
2 F G(2 \times 4)\end{array}$ \\
\hline 6 & $\begin{array}{l}\text { rural } 11-18 \\
\text { mixed } \\
\text { comprehensive }\end{array}$ & $\begin{array}{l}8 \\
(2 \text { obs })\end{array}$ & $\begin{array}{lr}3 & \text { Hum } \\
\text { Sci* }^{*} \text { Sci }\end{array}$ & $\begin{array}{l}4 / 12 \text { qs } \\
3 \text { discn }\end{array}$ & $\begin{array}{l}33 \text { qs } \\
(90 \%) \\
2 \mathrm{FG}(3,6)\end{array}$ \\
\hline 7 & $\begin{array}{l}\text { urban } \\
\text { /suburban 11- } \\
18 \text { boys' }\end{array}$ & $\begin{array}{l}5 \\
\text { (2 obs) }\end{array}$ & $\begin{array}{l}\text { No } \\
\text { (Sci })\end{array}$ & $\begin{array}{l}3 / 7 \mathrm{qs} \\
1 \mathrm{discn}\end{array}$ & $\begin{array}{l}19 \text { qs } \\
(60 \%) \\
2 \mathrm{FG}(4,5)\end{array}$ \\
\hline
\end{tabular}




\begin{tabular}{llllll}
\hline & selective & & & & \\
\hline 8 & urban 11-18 & 8 & No & $6 / 9$ qs & $41 \mathrm{qs}$ \\
& girls' & (2 obs) & $\left(\right.$ Sci $\left.^{\star} \mathrm{RE}\right)$ & 2 discn & $(90 \%)$ \\
& comprehensive & & & & $2 \mathrm{FG}(2 \times 5)$ \\
\hline
\end{tabular}

Key: (2 obs) two classes were observed throughout the day in each school

Teacher data *Discipline of co-ordinating teacher

4/4qs - proportion of questionnaires obtained - no collected/ total number of teachers

3 discn - number of teachers involved in informal discussion with research team

Pupil data $19 \mathrm{qs}(60 \%)$ number of questionnaires collected; approx percentage of those distributed

2 FG $(2 \times 5)$ number of focus groups and number of pupils in each group

Focus group discussions were transcribed and coded reflexively for major themes in pupils' responses. A qualitative data software package (NUD*IST NVivo) was used to assist in the mechanics of coding to allow exploration of the extent to which themes were common to different groups. For each school a member of the research team used all relevant data, including materials given to pupils, to build up an extensive document describing pupils' and teachers' experiences of the programme in that school. Another member of the research team, who observed the programme, read through and verified, or amended following discussion, the summary of that school's experience. These extensive portraits, coding of focus group discussions and quantitative analysis of questionnaires formed the evidence base for the evaluation.

\section{Results}

Although 11 schools were recruited to deliver the programme, three withdrew for reasons related to the general barriers of implementing collapsed days i.e. the extensive time needed for planning; logistical difficulties in organisation. Across the eight schools delivering the programme, there was considerable variation in design and implementation. The six schools whose teachers had attended the development day adapted the outline programme in a number of ways. The two schools whose teachers did not attend the development day incorporated more elements of the original design as they stood but still had quite different programmes. The adaptation was expected. What is interesting is the extent to which the key aim of pupils' engagement in considering social and ethical aspects of genetics through a cross-curricular approach was achieved and supported.

Table 2 Collapsed day programme as declared in each school's planning

\begin{tabular}{|l|r|l|l|l|l|l|l|l|l|l|}
\hline & & & \multicolumn{7}{|c|}{ School } \\
\hline Activity & $\begin{array}{l}\text { Total } \\
\text { number } \\
\text { schools }\end{array}$ & $\begin{array}{l}\text { Research } \\
\text { team }\end{array}$ & 1 & 2 & 3 & 4 & 5 & 6 & 7 & 8 \\
\hline Introductory Stimulus & 8 & $\sqrt{ }$ & $\sqrt{ }$ & $\sqrt{ }$ & $\sqrt{ }$ & $\sqrt{ }$ & $\sqrt{ }$ & $\sqrt{ }$ & $\sqrt{ }$ & $\sqrt{ }$ \\
\hline Team building & 4 & $\sqrt{ }$ & $\sqrt{ }$ & X & X & $\sqrt{ }$ & X & X & $\sqrt{ }$ & $\sqrt{ }$ \\
\hline Evaluation of prior knowledge & 3 & $\sqrt{ }$ & $\sqrt{ }$ & X & $\sqrt{ }$ & X & X & X & X & $\sqrt{ }$ \\
\hline What do we know (science) & 8 & $\sqrt{ }$ & $\sqrt{ }$ & $\sqrt{ }$ & $\sqrt{ }$ & $\sqrt{ }$ & $\sqrt{ }$ & $\sqrt{ }$ & $\sqrt{ }$ & $\sqrt{ }$ \\
\hline $\begin{array}{l}\text { How do we know (science } \\
\text { extension) }\end{array}$ & 1 & Opt & X & X & X & X & X & X & $\sqrt{ }$ & X \\
\hline
\end{tabular}




\begin{tabular}{|c|c|c|c|c|c|c|c|c|c|c|}
\hline $\begin{array}{l}\text { What are our views? (opinion } \\
\text { forming) }\end{array}$ & 8 & $\sqrt{ }$ & $\sqrt{ }$ & $\sqrt{ }$ & $\sqrt{ }$ & $\sqrt{ }$ & $\sqrt{ }$ & $\sqrt{ }$ & $\sqrt{ }$ & $\sqrt{ }$ \\
\hline $\begin{array}{l}\text { How do we decide? (ethical } \\
\text { analysis) }\end{array}$ & 7 & $\sqrt{ }$ & $\sqrt{ }$ & $\sqrt{ }$ & $\sqrt{ }$ & $\mathrm{X}$ & $\sqrt{ }$ & $\sqrt{ }$ & $\sqrt{ }$ & $\sqrt{ }$ \\
\hline Synthesis activity for pupils & 7 & $\sqrt{ }$ & $\sqrt{ }$ & $\sqrt{ }$ & $\sqrt{ }$ & $\sqrt{ }$ & $\mathrm{X}$ & $\sqrt{ }$ & $\sqrt{ }$ & $\sqrt{ }$ \\
\hline $\begin{array}{l}\text { Tangible product (poster / video } \\
\text { etc) }\end{array}$ & 3 & $\sqrt{ }$ & $\sqrt{ }$ & $\sqrt{ }$ & $\mathrm{X}$ & $\mathrm{X}$ & $\mathrm{X}$ & $\mathrm{X}$ & $\mathrm{X}$ & $\sqrt{ }$ \\
\hline Plenary - sharing outcomes & 5 & $\sqrt{ }$ & $\sqrt{ }$ & $\mathrm{X}$ & $\sqrt{ }$ & $\sqrt{ }$ & $?$ & $\sqrt{ }$ & $\sqrt{ }$ & $\mathrm{X}$ \\
\hline $\begin{array}{l}\text { Cumulative (assessable ) pupil } \\
\text { record }\end{array}$ & 4 & $\sqrt{ }$ & $\mathrm{X}$ & $\sqrt{ }$ & $\mathrm{X}$ & $\mathrm{X}$ & $\sqrt{ }$ & $\mathrm{X}$ & $\sqrt{ }$ & $\sqrt{ }$ \\
\hline Follow-up work & 2 & $\sqrt{ }$ & $\sqrt{ }$ & $?$ & $?$ & $?$ & $?$ & $?$ & $X$ & $\sqrt{ }$ \\
\hline
\end{tabular}

Table 2 shows the elements of the programme as planned for in each of the eight schools. Although Table 2 shows some clear commonalities in the type of activities planned for by different schools, it hides considerable differences between the activities as constructed and delivered. All schools planned to use some type of stimulus to start the event; had at least one activity which explored knowledge of genetics necessary to understand the issue; expected pupils to engage in discussion and/or debate in sharing their opinions. All but one school planned to use ethical analysis. However, even these common activities took different final forms both in the schools' plans and in implementation.

We now return to the three research questions and consider them in turn, drawing on the extensive evaluation evidence; the outcomes of the initial feasibility questionnaire; and field notes and focus groups during development day.

o What are the learning outcomes for pupils from a 'collapsed day' on social aspects of genetics?

0 What are the gains and barriers for teaching and learning in crosscurricular collaboration?

o What are the opportunities and barriers for teachers in their planning for and delivering 'collapsed days' in principle and in practice?

\section{Learning outcomes for pupils}

The feasibility questionnaire provided background evidence of teachers' expectations of a collapsed day. Although there were some differences in the detail of responses from the three types of participants - Headteachers, Heads of Science, Heads of Humanities - the main opportunities for having a collapsed day were seen by all as allowing a focused exploration of issues, without curricular constraints; encouraging cross-curricular and collaborative working on behalf of staff and complementing work in science with work in humanities. Respondents were presented with closed questions to rate possible learning opportunities for the day (Likert scale 1-5, with 1 showing strong agreement). 
Table 3 Mean extent of agreement with suggested learning opportunities, extent of assessment and follow-up work expected

\begin{tabular}{|l|r|r|r|}
\hline & \multicolumn{3}{|c|}{ Agreement with learning } \\
& outcomes \\
\hline Learning outcome & $\begin{array}{l}\text { Head- } \\
\text { teachers }\end{array}$ & $\begin{array}{l}\text { Heads of } \\
\text { science }\end{array}$ & $\begin{array}{l}\text { Heads of } \\
\text { humanitie } \\
\text { s }\end{array}$ \\
\hline Discussion of social aspects & 1.19 & 1.18 & 1.43 \\
\hline Analysis from an ethical perspective & 1.28 & 1.15 & 1.41 \\
\hline $\begin{array}{l}\text { Understanding of rights and } \\
\text { responsibilities }\end{array}$ & 1.43 & 1.27 & 1.31 \\
\hline Team work & 1.30 & 1.34 & 1.45 \\
\hline Learning relevant science & 1.58 & 1.72 & 1.59 \\
\hline Understanding of processes of science & 2.02 & 1.73 & 1.91 \\
\hline Creative expression & 2.17 & 2.00 & 1.63 \\
\hline
\end{tabular}

Low means indicate greater agreement

All suggested learning opportunities were viewed positively, with means for each sample all showing strong or moderate agreement with the suggested learning outcome (Table 3). Discussion of social aspects and ethical analysis showed the strongest support across respondents, with creative expression and understanding the processes of science ranking lowest. However, differences were not great. Learning of relevant science was seen to go alongside learning outcomes related to social and ethical aspects. It might be expected, then, that several of the suggested learning outcomes could be a focus for a collapsed day and, indeed, multiple learning outcomes would be sought by teachers.

The programme in principle provided the opportunity for learning with respect to all the highly rated learning outcomes (see Figure 2). The lowest rated learning outcomes - understanding the processes of science and creative expression - were shown as optional in the design of the framework as presented to teachers. Evaluation of implementation allowed perceptions of extent of achievement of the highly rated learning outcomes.

Aims of the day

Pupil questionnaires and focus groups allowed identification of perceptions of the focus of the event and detail of learning. While pupils in all schools recognised the event as being about aspects of advancements in genetics, some did not appreciate that an additional key aim was to consider aspects of ethics or decision-making (Table 4).

Table 4 Pupils' perceptions of what the event was about

\begin{tabular}{|l|c|c|c|c|c|c|c|c|}
\hline & \multicolumn{7}{|c|}{ School } \\
\hline $\begin{array}{l}\text { Questrument } \\
\text { e }\end{array}$ & 1 & 2 & 3 & 4 & 5 & 6 & 7 & 8 \\
\hline
\end{tabular}




\begin{tabular}{|c|c|c|c|c|c|c|c|c|}
\hline \begin{tabular}{|l} 
Focus \\
groups
\end{tabular} & Genes & $\begin{array}{l}\text { Genes } \\
\text { Ethics }\end{array}$ & Genes & Genes & Views & $\begin{array}{l}\text { Genes } \\
\text { Views }\end{array}$ & $\begin{array}{l}\text { Genes } \\
\text { Ethics }\end{array}$ & $\begin{array}{l}\text { Genes } \\
\text { Ethics }\end{array}$ \\
\hline
\end{tabular}

Terms in brackets show a minority view $<30 \%$

Genes here is taken as a term to represent comments which relate to general and specific aspects of genetics or genetic engineering

Ethics refers to citations of ethics / moral aspects / decision-making

Views refers to sharing and hearing other people's views

Pupils' perceptions of the focus of the event may have been influenced by any publicity prior to the event (which was not collected by research instruments), the 'badging' of the event in terms of headings put on written work and the nature of the introduction and stimulus they received. While no causal relationship can be established, the way in which the event was introduced may have influenced pupils' perceptions of the main thrust of the event. During the development day, the teachers considered the nature of the stimulus as very important in grabbing pupils' attention at the start of the event. It is thus worth examining an introduction to illustrate features which seemed to promote an emphasis on both genetics and ethics. For example in school 7, the RE teacher from school 2 introduced the day:

Outside speaker took an approach of raising questions such as: Who are we? What can new genetics do? Have we become the new creators? What's in it for me? What would you change about yourself? Should we have designer babies? What of ethics? Mentions rights and responsibilities. (Throughout this the Powerpoint presentation devised by the research team was running). There was a short interactive activity, highlighting differences between pupils in hair colour and asking whether there should be genetic discrimination on this basis in future. [from Field notes School 7]

As shown in this extract, in the introductory stimulus questions were raised without providing answers or means of addressing the questions. Thus pupils at the start of the event were exposed to controversy and expectations were raised that they would consider that controversy during the day.

\section{Learning outcomes}

From experience of the day as a whole, in the questionnaire and in focus groups pupils expressed their views of the main aspects they had learnt (Table 5).

Table 5 Pupils' perceptions of what they learnt

\begin{tabular}{|c|c|c|c|c|c|c|c|c|}
\hline & \multicolumn{8}{|c|}{ School } \\
\hline & 1 & 2 & 3 & 4 & 5 & 6 & 7 & 8 \\
\hline Learnt & $n=40$ & $\mathrm{n}=25$ & $n=32$ & $n=14$ & $n=37$ & $n=33$ & $n=19$ & $n=41$ \\
\hline Genetics & $\#$ * 1.9 & * 2.0 & 2.4 & $\#$ * 2.5 & ${ }^{*} 2.1$ & * 1.9 & ${ }^{*} 2.0$ & * 1.7 \\
\hline my own views & 2.1 & \# 2.1 & 2.3 & 2.4 & 2.0 & 2.3 & 2.3 & \# 2.0 \\
\hline Other people's views & & * & \#* & & * & & & \\
\hline
\end{tabular}




\begin{tabular}{|l|r|r|r|r|r|r|r|r|}
$\begin{array}{l}\text { how to express views in } \\
\text { different ways }\end{array}$ & 2.5 & 2.4 & 2.5 & 1.9 & 2.3 & 2.6 & 2.5 & 2.3 \\
\hline $\begin{array}{l}\text { how to decide what's } \\
\text { right and wrong }\end{array}$ & 2.3 & 2.3 & 2.5 & 2.0 & 2.2 & $* 2.2$ & 2.2 & $* 2.1$ \\
\hline $\begin{array}{l}\text { People's rights and } \\
\text { responsibilities }\end{array}$ & $\mathbf{2 . 1}$ & $\mathbf{2 . 0}$ & 2.8 & 2.4 & 2.1 & 2.2 & 2.7 & 1.7 \\
\hline $\begin{array}{l}\text { How people can deal } \\
\text { with a complex issue }\end{array}$ & 2.2 & 2.4 & 2.3 & 2.4 & 2.0 & 2.2 & 2.6 & 2.1 \\
\hline Complexity of issues & & & & & $\#$ & $\#$ & $\#$ & \\
\hline $\begin{array}{l}\text { The processes of } \\
\text { science - HOW it's done }\end{array}$ & 2.4 & 2.4 & 3.0 & 2.5 & 2.7 & 2.5 & 2.6 & 2.6 \\
\hline $\begin{array}{l}\text { How to work as part of a } \\
\text { team }\end{array}$ & 2.4 & 2.1 & 3.2 & 2.3 & 2.3 & 2.7 & 3.2 & 1.9 \\
\hline
\end{tabular}

Numbers are the mean for responses to each closed question on the questionnaire 4 point scale used: $1=$ a lot; $4=$ a little Low means show greater learning

* indicates learning gains which were mentioned with high frequency (> $30 \%)$ in open questions on the questionnaire

\# indicates learning gains which were strongly supported in focus group

discussions

Emboldened figures show the 3 mostly highly rated learning in each school

In all but one school, learning about genetics was perceived as one of the most highly rated learning gains. However, pupils had difficulty pinpointing exactly what it was they had learnt about genetics, in open questions and in focus group discussions:

P1: I think it is important if you want to build your family to know if you have got the gene or if you are a carrier. I knew about it, but not in depth like this. I thought these were quite rare cases but it is not now. It is a bit scary.

P1: I did not know much about it before, but I was against it. You know this genetic modification on crops and stuff, but today did help to stabilize what I thought..

[Focus group School 2]

P4 How genetic engineering can solve lots of problems cos I always thought it was a bad thing but it can like solve world hunger and that can't it, I didn't really know it was any good [Focus group School 4]

P2 The questions in the booklet they made you think like about cystic fibrosis $P 1 \quad$ And how to improve it by genetically changing your genes and stuff with gene therapy [Focus group School 5]

A notable feature of such discussions is the value judgements which are apparent in considering the genetics learnt. Thus, although pupils showed an emphasis on learning genetics, this was not divorced from the social implications. These extracts give a flavour of the range of concepts which were addressed in different schools. It is interesting to examine what scientific background was being introduced or expected to be used. Table 6 shows the concepts explicitly explored in each school for ALL pupils - i.e. tasks where explanations of concepts were given; written work which used the concepts; or tasks which actively explored pupils' understanding of the 
concept. The table does NOT include terminology used in external speakers' introductions or concepts addressed in tasks which were undertaken by only some of the pupils in each school. 
Table 6 Scientific concepts addressed during each collapsed day programme

\begin{tabular}{|c|c|c|c|c|c|c|c|c|}
\hline $\begin{array}{l}\text { Keyword } \\
\text { sheet } \\
\text { Provided by } \\
\text { research } \\
\text { team }\end{array}$ & $\begin{array}{c}1 \\
\text { Year } 10 \\
\text { (14-15 yr } \\
\text { olds) }\end{array}$ & $\begin{array}{c}2 \\
\text { Year } 10\end{array}$ & $\begin{array}{l}3^{\text {Scho }} \\
\text { Year } 10\end{array}$ & $\begin{array}{c}4 \\
\text { Year } 11 \\
\text { (15-16 yr } \\
\text { olds) }\end{array}$ & $\begin{array}{c}5 \\
\text { Year } 11\end{array}$ & $\begin{array}{c}6 \\
\text { Year } 11\end{array}$ & $\begin{array}{c}7 \\
\text { Year } 10\end{array}$ & $\begin{array}{c}8 \\
\text { Year } 11\end{array}$ \\
\hline $\begin{array}{l}\text { Chromosome } \\
\text { Clone } \\
\text { DNA } \\
\text { Gene } \\
\text { Gene } \\
\text { therapy } \\
\text { Genetic } \\
\text { testing } \\
\text { Germ cells } \\
\text { Germ-line } \\
\text { genetic } \\
\text { modification } \\
\text { Genetic } \\
\text { engineering } \\
\text { Genome } \\
\text { GMO } \\
\text { Somatic cells } \\
\text { Cystic } \\
\text { fibrosis } \\
\text { Freidreich's } \\
\text { Ataxia }\end{array}$ & $\begin{array}{l}\text { Fertilisation } \\
\text { Cell } \\
\text { Nucleus } \\
\text { Chromosome } \\
\text { Gene } \\
\text { Recessive } \\
\text { Dominant } \\
\text { Inherited } \\
\text { disorder } \\
\text { Genetic } \\
\text { testing }\end{array}$ & $\begin{array}{l}\text { Chromosome } \\
\text { Genetic } \\
\text { engineering } \\
\text { Genetic } \\
\text { testing } \\
(\text { The Gift *) } \\
\text { Recessive } \\
\text { Dominant } \\
\text { Inherited } \\
\text { disorder } \\
\text { Embryo } \\
\text { selection } \\
\text { Freidreich's } \\
\text { Ataxia }\end{array}$ & $\begin{array}{l}\text { Chromosome } \\
\text { Fertilisation } \\
\text { DNA } \\
\text { Gene } \\
\text { Recessive } \\
\text { Dominant } \\
\text { Inherited } \\
\text { disorder }\end{array}$ & $\begin{array}{l}\text { (The Gift *) } \\
\text { Recessive } \\
\text { Dominant } \\
\text { Inherited } \\
\text { disorder } \\
\text { Embryo } \\
\text { selection } \\
\text { Freidreich's } \\
\text { Ataxia } \\
\text { GM plants }\end{array}$ & $\begin{array}{l}\text { Inherited } \\
\text { disorder } \\
\text { Genetic } \\
\text { crosses }\end{array}$ & $\begin{array}{l}\text { Cell } \\
\text { Nucleus } \\
\text { DNA } \\
\text { Chromosome } \\
\text { Genetic } \\
\text { crosses } \\
\text { (The Gift *) } \\
\text { Recessive } \\
\text { Dominant } \\
\text { Inherited } \\
\text { disorder } \\
\text { Embryo } \\
\text { selection } \\
\text { Freidreich's } \\
\text { Ataxia } \\
\text { Achondroplasis } \\
\text { Huntington's } \\
\text { chorea }\end{array}$ & $\begin{array}{l}\text { DNA } \\
\text { DNA } \\
\text { replication } \\
\text { Protein } \\
\text { structure } \\
\text { Genetic } \\
\text { inheritance } \\
\text { Genetic } \\
\text { engineering } \\
\text { Plus } \\
\text { Keyword } \\
\text { sheet } \\
\text { Cystic } \\
\text { fibrosis } \\
\text { Sickle cell } \\
\text { anaemia }\end{array}$ & $\begin{array}{l}\text { Gene } \\
\text { Chromosome } \\
\text { Recessive } \\
\text { Dominant } \\
\text { Symptomless } \\
\text { carrier } \\
\text { Human } \\
\text { genome } \\
\text { Genetic } \\
\text { crosses } \\
\text { Genetic } \\
\text { engineering }\end{array}$ \\
\hline
\end{tabular}

* In the video 'The Gift' the inheritance of Freidreich's Ataxia is explained and the concept of embryo selection is embedded in the drama. Schools showing this in full to all pupils are shown. 
In nearly all schools the nature of genetic inheritance was explored explicitly through group tasks allowing pupils to understand the nature of genetic crosses involving dominant and recessive genes. Thus in one school, for example:

Pupils were each given cards describing their genetic status as germ cells e.g. $X$ or $Y$ chromosome, presence of dominant or recessive gene for: tongue rolling; black hair, cystic fibrosis; hairy joints. Pupils were physically moved so that there were two lines facing each other. Two pupils were then selected to discover what the characteristics of their offspring would be. The gene combinations were recorded on the board and the pupils appeared to grasp issues of dominant and recessive genes quite quickly. [from School 3 field notes]

In other schools, genetic crosses were explored by less interactive methods, for example the construction of punnet diagrams in a whole class question and answer session; watching an explanation presented by video.

Two schools explicitly tackled the mechanism of genetic engineering. For example, in one school an innovative task allowed some development of understanding of genetic engineering:

Each teacher used a web-based presentation to show the principles of genetic engineering. The presentation was comprehensive, pitched at the pupils' level but nonetheless seemed difficult for pupils to follow. The pupil activity was to design a genetically engineered organism and present this on a poster. The expectations were indicated for pupils to show: how they would get the DNA out of one organism, select the gene wanted, copy it, alter it slightly to suit the purpose, get it into the organism, then breed the organism. One teacher gave an example of an apple tasting of cinnamon. The other indicated chocolate milkshake straight from the cow.

Groups were considered to be 'on-task' but seemed engaged at a fairly low level of understanding. However, two groups were able to explain GE at a simple level to the observer. For some the production of the poster did seem to help them consider and explain GE at a simple level and towards the end of the lesson there seemed some real insights from a minority of pupils about genetic transformations. Some outcomes as shown in posters were: a bat with a lion's roar; a nicotine flavoured apple; an apple the shape of a banana; a panda with a frog's colour. However, pupils did not indicate the purpose or possibility of these genetic transformations. [School 4 field notes]

In most schools, the process of genetic engineering was not explained in any detail. Rather an understanding of genetic modification was based on the principle of genes as the vehicle for determining an organism's characteristics and capable of being changed in some way. This research project has raised an unresolved question - What level of scientific understanding is needed to discuss the implications of advancements in genetics, particularly genetic engineering?

Some appreciation of the level of understanding needed and used may be gleaned from pupils' input into 'synthesis' activities - those in the latter half of the programme drawing different elements together.

The framework presented to teachers on the development day allowed for flexibility in the way in which pupils might synthesise their learning outcomes - 
using two key questions - What is possible? How should we decide? Two main approaches to synthesis were adopted by schools - a debate involving half or full year groups; small groups working on particular tasks each with an tangible outcome which could be displayed.

Debate was used in three schools. For example, pupils in school 6 in halfyear groups considered the motion 'This house believes reproduction should be left to chance'. In the debates, it was difficult to judge the nature of the learning outcomes for many of the pupils from observation. It is also difficult from the pupils' questionnaire data to attribute learning gains to involvement in debate rather than any other aspect of the collapsed day programme. Some particular comments from questionnaires and focus groups, however, give pointers to what pupils saw as enjoyable. For example, in one school conducting a debate, in responses to an open question on the questionnaire the debate was cited with highest frequency $(36 \%)$ as the activity most enjoyed. In another school, discussion in focus groups showed that pupils valued hearing experts and others' opinions ("I liked question time - it gives you the chance to hear views and opinions") but felt the panel discussion was rather long with limited opportunities for active learning.

In three other schools tangible products resulted from small groups of pupils working on particular issues. For example in school 1, each class of pupils was given a particular task, chosen according to their expected level of critical engagement with the issues. Thus activities were: design of a message about genetic engineering to go on a T shirt; production of a TV debate involving pupils acting out roles of people taking different positions on human cloning; production of a powerpoint presentation showing arguments for and against genetic engineering. For all three activities, clear briefing sheets for teachers were produced to show key skills being developed, citizenship and literacy links and a suggested lesson outline. Pupils were encouraged to develop clear arguments and use terminology clearly and correctly. Pupils engaged in their given activities with enthusiasm for the hour and 20 minutes showing very little off-task behaviour. Teachers in questionnaire responses also supported the enthusiasm and sustained attention which pupils gave the tasks.

The presentations resulting from tangible products, as in the debates, were strong on pupils showing their opinions. Specialist terminology, such as genetic engineering, cloning, cystic fibrosis, was used comfortably but without explicit discussion of the concepts. The nature of discussion both within pupils' presentations and during group discussion seemed similar to that observed in previous research (Solomon, 1992; Ratcliffe 1997) - that is scientific evidence was drawn into discussions with low frequency but familiarity with science terms and concepts underpinned discussions. The fact that genetic engineering, for example, is used as an unproblematic term in pupils' discussions suggests a sufficient understanding to engage with the issue. However, the exact nature of this 'sufficient' understanding is open to debate and worthy of further study. 
It would be nice to have a clear, straightforward answer to the question Overall what did pupils learn from their experience of a collapsed day on the social and ethical implications of genetics? In practice, there is no clear-cut answer. However, in the synthesis activities and in focus group discussions, pupils were able to show evidence of bringing together different views on issues involving genetics i.e. supporting a view that pupils were able to come to an informed stance on the social impact of advancements in genetics, recognising their own views and those of other people.

Having a focus on a tangible product, as advocated by the research team, seemed to promote active engagement by a wide range of pupils, providing opportunities for differentiation and acknowledgement of different learning styles.

Pupils appreciated the opportunity to share perspectives and engage in discussion, with peer group discussion amongst the three most highly rated activities for enjoyment and learning in each school, from the pupil questionnaires. It is worth examining the activities of peer group discussion and ethical analysis in more detail. These were areas were the potential existed for effective cross-curricular collaboration between teachers with complementary skills and support for pupils' learning. It is to the second research question we now turn: What are the gains and barriers for teaching and learning in cross-curricular collaboration?

Cross-curricular collaboration in supporting learning Cross-curricular collaboration was a feature of the whole programme. For the purposes of this paper we focus on peer group discussion and ethical analysis, given their potential for learning and their focus in earlier research (Levinson and Turner, 2001). Within each school there were opportunities for pupils to develop opinions and share them with other pupils. For example, in school 8 , groups of up to 9 pupils discussed and recorded their prior understanding; discussed outcomes of different activities which members of the team had attended and then took a group approach to synthesis of views through construction of a 'product'. Observations of the session where pupils shared outcomes from the different activities were revealing:

This session principally involved peer teaching, discussion or in the 'weakest' cases dictation of notes from one person to the whole group. In most groups the feedback was not just sharing notes, but pupils took the opportunity to discuss ideas, asking questions of each other. There were heated discussions amongst some groups. Pupils showed enough understanding to probe each other. They showed features of good discussion i.e. listened to each other or self-regulated within group to interrupt / ask questions /bring order. Teacher circulated and listened but did not interrupt / scaffold unless necessary. [From School 8 field notes]

As the quality of discussion happened with little introduction by the teacher, it would appear that pupils in this school were practised in small group discussion. In other schools, such self-regulated group discussion happened with far lower frequency. Teachers made deliberate opportunities for pupils to discuss with each other, mostly in groups not 
formed by friendship but to get a mixture of achievement and character. The following two extracts are typical of the operations in five schools:

In both classes observed, there was mixed response to the scenarios - some groups were able to carry out a discussion with minimal support; others needed substantial contact with a teacher to keep them on task and focussed. A group in one class near the observer were overheard. They initially did get engaged with the problem - however the discussion ran out of steam fairly quickly and pupils then engaged in off-task talk. Teachers circulated to the different groups but there was a tendency to stay with one group for a considerable period of time. [school 5 field notes]

In groups of about 10 pupils they had to brainstorm their ideas. The teacher moved from group to group to prompt and get pupils discussing ideas. In this class the pupils had little disagreement about their responses and little was made of inconsistencies within their thinking. For example, pupils were unhappy with the idea that the person sitting next to them might be genetically engineered but didn't see a problem if there were no genetic mishaps in society. [school 2 field notes]

Some discussion activities had a format which was more inclined than others to provoke critical discussion. For example in school 3 pupils were given information about a particular genetic dilemma:

They then each clarified their own views on a 1-10 continuum - e.g. It is wrong to create a baby so that it can be used to save the life of another child ( 1 - I strongly disagree; 10 - I strongly agree). Each group of pupils was then asked to discuss the extent to which they agreed with the statements and why, noting reasons for agreeing and disagreeing.

However, even here teachers had to work hard in asking questions of each group which provoked clear debate rather than leaving pupils to complete the task with little critical thought, particularly evident where there was ready consensus.

There was a sense from the observations of the group discussions that scaffolding which encouraged the challenging of different viewpoints could have encouraged a more critical exchange of views. It appeared that there were some missed learning opportunities within the discussions. The skills and ground rules for critical discussion were not made explicit to pupils. One limiting factor, perhaps inevitably, was time. In several schools, the time allocated for discussion was shorter than might be needed to give due consideration to the complexity of the issue under discussion. There was perhaps an underlying, and in a few cases justifiable, fear that pupils would not sustain group discussion for any length of time. Teachers' prior experience in supporting peer group discussion is unknown. However, it might be expected that what was seen reflected teachers' normal practice or interpretation of the task rather than any development during crosscurricular planning. Thus our expectations that humanities teachers might support peer group discussion more effectively than science teachers or that cross-curricular planning and implementation might result in support for peer group discussion such as that seen in school 8 was not borne out. 
Similar issues emerged in activities where pupils were engaged in ethical analysis but with apparently more missed opportunities for scaffolding pupils' learning.

The process of using Goals, Rights and Responsibilities (GRR) as one method of ethical analysis was new to all teachers participating in the project. Those schools addressing the ethics of the genetics issue all chose to use the GRR approach in enabling pupils to consider the issue. (Some used other activities in addition.) However, there were different interpretations of this approach and different levels of expertise. This is perhaps best exemplified by contrasts within the same schools:

\begin{abstract}
Pupils had to focus most of their discussion on a number of different scenarios, regarding GRR. In one observed class this was a poorly focused session, whilst in the other observed class some skilful chairing of discussion kept the momentum going. It seemed clear from observation that the staff had not fully understood the GRR issue and so didn't fully explain the distinction between them, how they might come into conflict with each other, which then needs to be addressed someway. Pupils were able to produce some thoughtful responses, but little time was given to unpacking the thinking behind the decision-making processes of the pupils. [school 1 field notes]
\end{abstract}

In one observed class, groups of pupils were given 10 minutes to complete this task. Pupils were given little explanation of $G, R, R$ and it was not made clear to them how they would feed back their ideas. Many worked sensitively on this task. 10 minutes was given over to feedback to the class, though the quality of feedback was variable. In another class pupils were given 45 minutes for the task, had an example explained and were able to work in smaller groups. Once they were clear about $G, R, R$ they were able to work thoughtfully. This class were able to discuss the nature of $G, R, R$ well during feedback. [school 2 field notes]

This second extract shows a comparatively rare event - the teacher reflecting with the pupils on the ethical principles being used. The combination of giving the activity considerable time and drawing on the (RE) teacher's own expertise allowed for clarification of the nature of ethics. Pupils' level of understanding increased as a result allowing pupils in focus group discussion to articulate that they had learnt about ethics: Messing about with genetics, is it right or wrong, is it morally right, if it is allowed. Ethical decisions which I did not know anything about before.[school 2 focus group]

Where ethical analysis was led by a teacher with expertise in both ethics and managing discussion and there was sufficient time to explore principles, the level of pupils' engagement with ideas of Goals, Rights and Responsibilities was high.

Although having a task on ethical analysis allowed pupils an introduction to some ethical principles, the pockets of expertise within the participating schools were not always shared.

In both cases of peer group discussion and ethical analysis, the activity seemed for most teachers NOT to be part of their repertoire of teaching strategies, the exception being RE teachers. In most cases cross-curricular collaboration did not extend to an effective sharing of teaching strategies - 
i.e. there was not transfer of expertise between teachers of different disciplines. More detail of cross-curricular collaboration is gained by considering the third research question - What are the opportunities and barriers for teachers in their planning for and delivery of 'collapsed days' in principle and practice?

Opportunities and barriers in cross-curricular collaboration In designing the development day and supporting the subsequent planning and delivery in schools, the research team were interested to see to what extent true cross-curricular collaboration in delivery really happened approach $\mathrm{C}$ in Figure 1.

Table 7 shows an overview of the nature of cross-curricular planning in each school. The size of the team planning and delivering the programme varied from 4 teachers in one school to 14 in the larger schools. In might be expected that the smaller schools would have more scope for cross-curricular collaboration of type $\mathrm{C}$. However in this small sample of schools, school size did not affect the nature of collaboration. Neither was there a relationship between the nature of collaboration and the profile given to the event by the senior management and teachers involved. In schools where the profile of the event is categorised as high, commitments were made to involve outside speakers extensively, publicise the event within the community and alter the nature of the timetabled day for pupils involved. In schools where the profile is categorised as low, the programme was constructed to fit existing timings of the day and limited internal publicity was given of the event. Collaboration of types A and B was seen in both low and high profile events. However, only in one school (high profile event) was collaboration of type $C$ undertaken. The choice of collaboration seemed to depend on logistics of arrangements, such as cover for teachers involved in delivery, the pre-existence of team approaches to planning and previous experience of the challenge of collapsed days.

Table 7 Overview of teachers involved in delivery

\begin{tabular}{|c|c|c|c|c|c|c|c|c|}
\hline & \multicolumn{8}{|c|}{ School } \\
\hline & 1 & 2 & 3 & 4 & 5 & 6 & 7 & 8 \\
\hline $\begin{array}{l}\text { Lead } \\
\text { teacher / } \\
\text { Contact }\end{array}$ & RE & RE & $\begin{array}{l}\text { Team } \\
\text { RE Eng } \\
\text { Science }\end{array}$ & Science & Science & Science & Science & Science \\
\hline $\begin{array}{l}\text { Number of } \\
\text { 'classes' }\end{array}$ & 7 & 4 & 9 & 8 & $\begin{array}{l}8 \\
(2 \times 4)\end{array}$ & 8 & 5 & 8 \\
\hline $\begin{array}{l}\text { Number of } \\
\text { teachers } \\
\text { delivering }\end{array}$ & $\begin{array}{l}14 \\
7 \text { Sci } \\
7 \text { Hum } \\
(4 \\
\text { RE) }\end{array}$ & $\begin{array}{l}4 \\
2 \mathrm{Sci} \\
2 \mathrm{Hum} \\
(1 \mathrm{RE})\end{array}$ & $\begin{array}{l}9 \\
4 \text { Sci } \\
5 \text { Hum } \\
\\
(1 \mathrm{RE})\end{array}$ & $\begin{array}{l}11 \\
4 \text { Sci } \\
5 \text { Hum } \\
2 \text { ICT } \\
\text { (0 RE) }\end{array}$ & $\begin{array}{l}10 \\
4 \text { Sci } \\
2 \text { Hum } \\
4 \text { GTs } \\
\text { (2 RE) }\end{array}$ & $\begin{array}{l}12 \\
5 \mathrm{Sci} \\
5 \mathrm{Hum} \\
2 \mathrm{ICT} \\
(1 \mathrm{RE})\end{array}$ & $\begin{array}{l}7 \\
2 \text { Sci } \\
5 \text { Hum } \\
\text { (1 RE) }\end{array}$ & $\begin{array}{l}9 \\
4 \text { Sci } \\
5 \text { Hum }\end{array}$ \\
\hline $\begin{array}{l}\text { Type of } \\
\text { collaboration }\end{array}$ & C & $B$ & B & B & $B$ & $A$ & $A$ & $B$ \\
\hline $\begin{array}{l}\text { Profile of } \\
\text { event }\end{array}$ & High & Medium & High & High & Low & High & Low & High \\
\hline
\end{tabular}


GT - Group tutors with pastoral responsibility for the class

It may be unrealistic to expect cross-curricular planning of one event to allow not only sharing of the nature of activities undertaken in different disciplines but also development of expertise in using processes undertaken in disciplines other than the teacher's own. Prior experience in cross-curricular collaboration and the extent to which teachers had been involved in collapsed days in the past seemed to affect the focus of planning. Thus teachers for whom both managing a collapsed day and cross-curricular collaboration were new perhaps inevitably focussed on aspects of organisation rather than on sharing teaching expertise.

Some summaries of cross-curricular collaboration drawn from questionnaire and observation data show the existence of some effective sharing of expertise:

There was a clear team approach to the planning of the day. All teachers were motivated and understood the expectations on them and the pupils. There had been extensive cross-curricular involvement in planning so that each teacher was able to lead activities outside their subject expertise. There was remarkable consistency between the two observed teachers (of different disciplines) in the way in which they organised and supported group work and the time they spent on different activities. Teachers were keen and able to reflect critically on the activities in collaborative discussion. [school 3]

Teachers were positive about the chance to work together, and cited sharing practice and seeing how others work as valuable. The biggest obstacle was time for preparation as a whole team, which was particularly difficult given the numbers of staff involved during the day. In addition, cover requirements were seen as a potential barrier to further projects. Some teachers commented that the success of the day depended on the energy and enthusiasm of a couple of key people who drove the day forward. This was clear from the planning meetings prior to the day that the biggest burden of planning fell on certain individuals. [school 1]

Thus the potential for genuine sharing of expertise, whether of type B or C, was able to be harnessed where all of the following were apparent:

- there was prior collaboration between teachers whether formal or informal - i.e. a strong ethos of sharing already existed;

- several planning meetings were held with all teachers who were involved in delivering the programme;

- teachers who planned particular activities were able to document and explain the purpose of the activity to each other and exemplify in detail a suitable method of conduct.

In school 3, in reflecting on the preparation for the day, a teacher argued that they should have given the pupils an ethical framework to help them develop their arguments and thinking, whereas in practice the time and effort went into developing and customising resources appropriately. This seems an important comment - Has the focus in preparation and delivery been on WHAT pupils will do rather than an emphasis on HOW teachers would develop pupils' abilities? In some schools (e.g. school 8), learning outcomes were shared 
explicitly with pupils whereas in some others the programme was task centred with little explanation of why pupils were undertaking particular tasks. Pupils were able to engage in ethical analysis, discussion and synthesis of opinions and evidence but with a limited input into exploring the nature of the processes undertaken.

However, cross-curricular planning for development of pupils' abilities takes time and dedication. Although there were small numbers of teachers questionnaires returned from some schools, a summary of responses across all questionnaires shows an overview of the perceptions of opportunities and barriers in cross-curricular collaboration. As far as gains are concerned, 94\% of respondents to an open question indicated that they valued the opportunity to share teaching expertise with colleagues in other departments, with $58 \%$ identifying something specific they had learnt from another curriculum area. Although $22 \%$ of respondents saw no barriers to cross-curricular collaboration, just over half $(52 \%)$ identified the time necessary for planning as the major drawback. Other barriers identified with low frequency included: the confusion of there being different approaches from different teachers; the organisation necessary and the need for more ethical input.

\section{Conclusions and implications}

Two strands have been present in this project:

- a 'collapsed day' as a vehicle for pupils' engagement with a socioscientific issue at a holistic level;

- the nature of effective cross-curricular collaboration in supporting such an event.

Pupils and teachers were positive about the collapsed day as providing a good opportunity for considering and social aspects of genetics. There was evidence that pupils started to develop informed views on genetics' issues, drawing on many of the facets expected in consideration of such issues e.g. concepts of genetics, ethical aspects of decision-making, making explicit and sharing personal views. Synthesis of the evaluation evidence discussed in the previous section suggests that the following aspects of the collapsed day are perceived as important in promoting pupils' engagement in considering social and ethical aspects of biomedical science:

o The study of one issue in depth, preferably of intrinsic interest to the pupils.

- A novel stimulus which raises questions about the social and ethical applications of genetics and sets the tone for the day.

o External speakers, seen as useful by teachers in providing both novelty and detailed expertise on the issue.

o Opportunities for pupils to voice and share their views, with this being most effective in small groups with a structure which supports critical discussion. 
o Ethical analysis in which pupils extend their appreciation of the moral dilemmas the issue raises and ways of addressing such complexity.

- An activity centred around the construction of a tangible product, allowing all pupils to synthesise their views actively and creatively.

o Pupils working in teams as a feature to reinforce active learning and critical discussion

The programme in design and implementation provided opportunities for these features to occur. However, the project has shown that expertise among both science and humanities teachers is patchy in being able to consider issues holistically. RE teachers seemed best able to support effective consideration of the social aspects of issues. The differing expertise was not always shared effectively. For the participating schools the experience of planning, sharing and delivery was perceived as demanding of time, resources and expertise. Nonetheless, the experience was regarded as positive in encouraging cross-curricular collaboration, with most schools indicating the likelihood of repeating the event, learning from this initial experience. However, it is not clear if these teachers, in developing the programme further, will continue to focus on the content and tasks which they expect pupils to cover or on the best methods of supporting learning - the latter encouraging further clarity in the teachers' role and sharing expertise. The experience of this project suggests that the cross-curricular collaboration necessary in planning and delivering a 'collapsed day' programme allows some recognition of differing expertise but limited development of individual teacher's skills. Considerable further professional development of both science and humanities teachers seems necessary to address socio-scientific issues fully, wherever they appear in the curriculum - as 'collapsed days' or elsewhere. This professional development may be facilitated by bringing science and humanities teachers together in a structured programme which focuses on the means of supporting peer group discussion and ethical analysis.

\section{References}

Bridges, D. (1979) Education, Democracy and Discussion. Windsor: NFER Publishing Company

Gayford C (1993) Discussion-based group work related to environmental issues in science classes with 15 year old pupils in England. International Journal of Science Education 15, 5, 521-529

Huckle, J (2001) Towards ecological citizenship In Lambert, D and Machon, P (eds) Citizenship through secondary geography London: Routledge/Falmer pp144-160

Kerr, D (1999) Re-examining citizenship education: the case of England Slough: NFER

Levinson, R. and Turner, S. (2001) Valuable Lessons: The teaching of social and ethical issues in the school curriculum, arising from developments in biomedical research - a research study of teachers The Wellcome Trust 
Ratcliffe, M (1997) Pupil decision-making about socio-scientific issues, within the science curriculum. International Journal of Science Education 19, 2, 1997 167-182

Ratcliffe, M (1999) Evaluation of abilities in interpreting media reports of scientific research. International Journal of Science Education 21, 10, 1085-1099

Ratcliffe, M and Grace M (2003) Science Education and Citizenship Buckingham: Open University Press

Solomon J. (1992) The classroom discussion of science-based social issues presented on television: knowledge, attitudes \& values. International Journal of Science Education 14, 4,431-444

Warnock, M (2001) An Intelligent Person's Guide to Ethics London:

Duckbacks 